УДК 352.071

https://doi.org/10.34142/24130060.2019.19.2.05

\title{
КОНТРОВЕРСІЙНІСТЬ ПРОЦЕСУ ДЕЦЕНТРАЛІЗАЦІЇ ВЛАДИ НА СУМЩИНІ: ПОЛІТИКО-ІНСТИТУЦІЙНИЙ ВИМІР
}

\author{
Г.М. Куц \\ Харківський національний педагогічний університет імені Г. С. Сковороди
}

\section{В.В. Нестеренко}

Національний інститут стратегічних досліджень

32014 року в Україні здійснюється реформа децентралізащії влади. Побічним ефектом від реформи децентралізащії, який певним чином нівелював ї̈ успіхи на Сумщині, став конфлікт між Сумською обласною радою та Сумською міською радою, щчо розпочався у кіниі 2018 р. і набув суттєвого загострення у 2019 р. Конфлікт пов'язаний з перереєстрацією підприємств обласної комунальної власності поза територією обласного иентру.

Власне кажучи, така ситуачія не сприяе суспільно-політичній стабільності в регіоні, оскільки існує ризик збурення громадськості. Зазначено, щяо через протистояння двох владних легітимних структур регіонального рівня існує ризик катастрофічного зниження рівня довіри населення до владних інститутів взагалі. Це потенційно формуватиме в очах населення образ держави як слабкої та нездатної у кризові моменти захистити своїх громадян. Через зменшення рівня надходжень податків до бюджету Сум можлива ситуачія, коли будуть недофінансовані або взагалі зупинені сочіальні програми та виплати мешканцям міста, щьо значно підірве авторитет ичентральної влади. Найгіршим є те, щзо означені ситуації протистоянь нівелюють успіхи реформи децентралізаиії.

Ключові слова: дечентралізачія, об 'єднана територіальна громада (ОТГ), влада, Сумшина, Сумська обласна рада, Сумська міська рада, конфлікт, політичні інститути.

\section{КОНТРОВЕРСИОННОСТЬ ПРОЦЕССА ДЕЦЕНТРАЛИЗАЦИИ ВЛАСТИ НА СУМЩИНЕ: ПОЛИТИКО-ИНСТИТУЦИОНАЛЬНОЕ ИЗМЕРЕНИЕ}

\section{Г.М. Куц, В.В. Нестеренко}

С 2014 года в Украине осуществляется реформа децеентрализаџии власти. Побочным эффектом от реформы децентрализации, который определенным образом нивелировал ее успехи на Сумшине, стал конфликт между Сумским областным советом и Сумским городским советом, начавшийся в конще 2018 г. и получивший существенное обострение в 2019 г. Конфликт связан с перерегистраџией предприятий областной коммунальной собственности вне территории областного центра.

Собственно говоря, такая ситуация не способствует общественно-политической стабильности в регионе, поскольку существует риск возмущения общественности. Отмечено, что из-за противостояния двух властных легитимных структур регионального уровня существует риск катастрофического снижения уровня доверия населения к властным институтам вообще. Это потенщиально будет формировать в 
глазах населения образ государства как слабого и неспособного в кризисные моменты защитить своих граждан. Из-за уменьшения уровня поступлений налогов в бюджет Сум возможна ситуация, когда будут недофинансированы или вообще остановлень сочиальные программы и выплаты жителям города, что значительно подорвет авторитет центральной власти. Хуже всего то, что указанные ситуации противостояния нивелируют успехи реформы децентрализации.

Ключевые слова: децентрализачия, объединенная территориальная община (ОТО), власть, Сумщина, Сумской областной совет, Сумской городской совет, конфликт, политические институты.

\section{CONTROVERSION OF THE DECENTRALIZATION PROCESS IN THE SUMY REGION: POLITICAL AND INSTITUTIONAL DIMENSION}

\section{H. Kuts, V. Nesterenko}

Since 2014 there has been a reform of power decentralization in Ukraine. The work experience and successful practices of already operating United Territorial Communities (UTCs) create the conditions for intensifying the reform processes with the broad involvement of residents, NGOs and local businesses.

A side effect of the decentralization reform, which to some extent offset its success in the Sumy region, was the conflict between the Sumy Regional Council and the Sumy City Council, which began in late 2018 and became significantly exacerbated in 2019. The conflict has to do with the re-registration of regional communal property enterprises outside the territory of the regional center. According to Sumy City Hall, the initiator of such re-registration was the Regional Council. The City Hall noted that because of this, the city budget was losing significant amounts of taxes, which would now be paid into local budgets of settlements of the region.

In the confrontation between the Sumy Regional Council and the Sumy City Council, the use of an arsenal of "dirty" political technologies was observed. In particular, patients with diabetes and diabetes mellitus became hostages of confrontation between the Sumy Regional Council and the Sumy City Council. This confrontation partly caused the situation of insufficient supply of patients with insulin drugs in the city of Sumy in spring and summer 2019.

In August 2019, the situation around the Sumy Regional Council enterprises, located in the city of Sumy, but re-registered in the districts of the region, intensified. Since, from the point of view of the representatives of the Sumy City Council, the city budget did not receive taxes from the enterprises that were legally transferred from the city to the districts of the region, the City Council is suing the Sumy Regional Council.

In fact, such a situation does not contribute to socio-political stability in the region, since there is a risk of public outrage caused by public splitoff by the authorities: residents of a large city (regional center) oppose residents of villages and towns in the region. Fighting for budgetary funds between governmental institutions can provoke deep societal splitoff between residents of villages and cities in the region. As Russia's hybrid war against Ukraine is based on creating and deepening social splitoffs, this situation could potentially be used by Russia in destructive informational technologies against the Sumy region with which it borders.

In addition, because of the confrontation between the two legitimate structures on the regional level, there is a risk of a catastrophic decline in the level of public confidence to government institutions in general. This will potentially shape the image of the state in the eyes of the population as weak and unable to protect its citizens in times of crisis.

Due to the decrease in the amount of tax revenues to Sumy budget, there may be a situation when underfunded or suspended social programs and payments to the city residents will significantly undermine the authority of the central government. The worst part is that these confrontation situations offset the success of the decentralization reform. 
Keywords: decentralization, united territorial community (UTC), power, Sumy region, Sumy Regional Council, Sumy City Council, conflict, political institutions.

Постановка проблеми. 32014 року в Україні здійснюється реформа децентралізації влади, яка $є$ домінантною у порядку денному реформування українського політичного простору. Досвід роботи та успішні практики вже працюючих об'єднаних територіальних громад (ОТГ) створюють умови для активізації процесів реформування 3 широким залученням мешканців, громадських організацій та представників місцевого бізнесу. Саме побудова ефективних комунікацій та співпраця органів місцевого самоврядування 3 мешканцями та бізнесом створюють умови для сталого розвитку територій, збільшення надходження податків до місцевих бюджетів. Підвищується активність виборців, які більш виважено ставляться до виборів депутатів та голови місцевої ради. Підвищується активність мешканців щодо участі в управлінні громадою, наприклад за рахунок підготовки проектів на конкурс партисипативних бюджетів.

Разом 3 тим, у процесі завершення процедури добровільного об'єднання територіальних громад прийшов час, коли існування двох систем управління територіальними громадами в Україні вже є ризикованим для людей та органів державної влади. 3 одного боку, створено більше 1000 об'єднаних територіальних громад (ОТГ), які взяли всю відповідальність за забезпечення надання послуг, розвитку територій тощо на себе, коли немає потреби керувати життям в громаді з району. 3 іншого боку, існує значна кількість сільських, селищних та міських рад, керівники яких протидіяли створенню ОТГ, переконували мешканців, що курс держави на передачу повноважень на базовий рівень $є$ тимчасовим, що децентралізацію відмінять, а сама ідея створення об'єднаних територіальних громад $є$ хибною.

Крім того, при переході до реформи наступного рівня субрегіонального, виникають конфлікти інтересів місцевих еліт. Означене коло проблем актуалізує проблематику дослідження контроверсійності процесу децентралізації влади на Сумщині. 
Аналіз актуальних досліджень. Проблематиці децентралізації присвячено наукові праці багатьох вітчизняних та зарубіжних теоретиків суспільно-політичного, державно-управлінського, політико-правового дискурсів (В. Авер'янов, М. Баймуратов, О. Безуглий, В. Борденюк, М. Геєнко, Р. Герцог, М. Гібернау, І. Грицяк, Я. Жаліло, Ю. Ковбасюк, О. Корнєва, Ю. Куц, І. Лукері, Н. Нижник, О. Роговенко, В. Оутс, Р. Патнам, М. Пухтинський, Л. Рибіна, О. Стогова, I. Шалигіна, В. Шаповал, О. Шевченко та ін.).

Метою статті стало виявлення контроверсійності процесу децентралізації влади на Сумщині у політико-інституційному контексті. Завдання статті полягає у виокремленні базових проблемних моментів процесу децентралізації на прикладі аналізу конфліктних взаємовідносин між Сумською обласною радою та Сумською міською радою, пов'язаних зі стартом реформи децентралізації.

Виклад основного матеріалу. Одним із ключових завдань реформ в Україні є забезпечення якості життя кожного громадянина незалежно від місця його проживання, достатку, віку, рівня освіти за рахунок активізації процесів інтегрування його в суспільне життя громади та використання ресурсу кожного мешканця. Завдання керівництва держави полягає у створенні умов для сталого розвитку спроможності територій громад, виходячи 3 бажання кожного мешканця жити в комфортних умовах та завдання органів місцевого самоврядування надавати якісні послуги, виконуючи власні та делеговані повноваження (Куц ред., 2011, 2013).

Реформа децентралізації вже продемонструвала, що українці мають бажання змінювати власне життя, брати на себе відповідальність та управляти життям у своїх громадах. На вересень 2019 р. В Україні створено близько 1000 об’єднаних територіальних громад (Міністерство регіонального розвитку, будівництва та житлово-комунального господарства України, 2019). Це території, де люди свідомо та добровільно прийняли рішення змінити власне життя та взяти владу в свої руки. Громада обирає собі владу, 
а влада ефективно використовує ресурси громади для створення гідних умов для життя, для економічного та соціального розвитку територій.

Владні структури здатні формувати комфортне середовище життя громади лише за умови активної співпраці між владою та громадою (Безрук, 2017). Разом з тим, постає необхідність посилення взаємодії на рівні «владагромада» задля ефективності процесу децентралізації в Україні. Адже владні органи часто стикаються 3 тим, що доволі важко переконати людей на місцях у перевагах децентралізації. Тобто, владні інституції змушені взяти на себе функцію переконання людей об’єднуватися у територіальні громади. Без ініціативи «знизу» (від конкретних активних представників громади) у жодної влади нічого не вийде, оскільки насаджені «зверху» примусові розпорядження рано чи пізно зазнають краху. Децентралізація - це всього лиш інструмент: якщо громада його ефективно використовує, то рівень комфортності життя пересічних мешканців швидко зростає. Але одночасно має значно зростати рівень відповідальності місцевої влади на рівні територіальної громади (Денисенко, 2015). На жаль, не всі готові брати на себе відповідальність. Причому, зустрічалися випадки, коли голови сіл та сільські ради певним чином саботують реформу децентралізації, розуміючи, що за нових умов треба буде набагато ефективніше та відповідальніше працювати.

Тобто, по лінії взаємодії «влада-громада» рух має бути двостороннім: влада має роз'яснювати переваги децентралізації, а громада має висувати активних ініціативних осіб, які здатні навчатися новому, здатні брати на себе відповідальність за інших. Задля ефективності процесу комунікації на рівні «влада-громада» варто залучати й науковців 3 просвітницькою метою, щоб (без використання наукової - складної для неспеціалістів - лексики) на прикладах роз'яснювали мешканцям села переваги реформи децентралізації. Наприклад, пояснювали, що за звичайнісінькою довідкою тепер можна буде сходити в сільську раду і отримати її на місці (роздрукованою з комп’ютера). Тобто, лінія взаємодії «влада-громада» може стати більш ефективною за 
умови долучення наукової спільноти задля роз'яснення переваг децентралізації.

У цьому контексті звернемося до прикладу з італійського досвіду, аналогії з яким є вельми повчальними для успішного здійснення реформи децентралізації в Україні. На початку 1970-х років XX ст., зазначає Р. Д. Патнам, почалися активні процеси децентралізації в Італії, коли відповідальність за охорону здоров'я, безпеку тощо перейшла від центрального до місцевих урядів (Патнам, Леонарді та Нанетті, 2001, с. 17). Одночасно було створено п’ятнадцять нових регіональних урядів 3 однаковою структурою. У цілому, місцевих урядів стало двадцять разом 3 п’ятьма вже існуючими на той момент регіональними урядами (які були розміщені в прикордонних районах Італії).

Слід зазначити, що ще з 1870 р. система управління в Італії була надто централізованою. Італія в минулому була могутньою монархією на півдні (візантійська культура) та низкою республіканських комун на півночі і у центрі (римська культура). Одразу проявилася регіональна специфіка ставлення до місцевих урядів. Якщо в Апулії (візантійський тип культури) проявлялася зневага до так званих місцевих функціонерів-нероб, зумовлена їхніми постійними фракційними суперечками «на візантійський кшталт» (Патнам, Леонарді та Нанетті, 2001, с. 18), то різким контрастом став уряд здавна католицької Венеції (римський тип культури). Відмінності між регіонами, як зазначає Р.Д. Патнам, зумовлені не лише територіальним чинником, але - більшою мірою - соціальними та релігійними факторами. Адже кожному регіону притаманні власні політичні традиції, коріння яких сягає давніх релігійних протиріч.

3 точки зору Р. Д. Патнама саме громадські об’єднання зміцнюють звичаї. Тобто, можна виявити прямий зв'язок між ефективністю та характером громадського життя. Адже «громадянська спільнота характеризується активністю людей, пройнятих духом громадянської єдності, егалітарними політичними відносинами, соціальною структурою 
довіри та співпраці» (Патнам, Леонарді та Нанетті, 2001, с. 29). У деяких регіонах Італії спостерігалися розгалужені мережі громадських об’єднань, що характеризувалися високим рівнем активності. Втім, існували регіони (візантійський тип культури), яким була притаманною вертикально структурована політика, фрагментарність та ізоляція в суспільному житті, культура недовіри. Саме ці відмінності стали основними у поясненні інституційного успіху. Отже, клімат довіри сприяє успіху демократизаційних перетворень та успішності реформи децентралізації, зокрема.

Відповідно, інституції здатні перетворювати політичне життя лише за умови їхньої кореляції з соціальним середовищем. Інституційним реформам не завжди під силу змінити людську поведінку.

Разом 3 тим, успішність практик децентралізації проявляється в тому, що формується потужна регіональна ідентичність, яка одночасно підсилює загальнонаціональну ідентичність (Куц, 2007). На думку М. Гібернау, процеси децентралізації детермінують переформатування ідентичностей: «багаторівневе врядування має тенденцію сприяти створенню кількох ідентичностей, які функціонують на різних рівнях» (Гібернау, 2012, с. 10). Причому, переважно виникають або зміцнюються два типи ідентичностей: регіональна та національна (Гібернау, 2012, с. 70).

Звернемося до аналізу практик децентралізації в Сумській області у політико-інституційному контексті. У рейтингу областей щодо формування спроможних громад Сумська область входить у десятку кращих областей України, посідаючи сьоме місце (Міністерство регіонального розвитку, будівництва та житлово-комунального господарства України, 2019, с. 10).

Згідно із Перспективним планом формування територій громад Сумської області, на Сумщині передбачено створення 53 об’єднаних територіальних громад (Офіційний сайт Сумської обласної ради, 2019).

На червень 2019 р. у Сумській області було створено 38 об'єднаних територіальних громад (ОТГ): «у 2015 році - Березівська ОТГ, у 2016 році 14 ОТГ: Бездрицька, Грунська, Дружбівська, Зноб-Новгородська, 
Миколаївська (Білопільський район), Миколаївська (Сумський район), Миропільська, Недригайлівська, Боромлянська, Нижньосироватська, Хотінська, Кириківська, Тернівська та Шалигинська, у 2017 році - 15 ОТГ: Кролевецька, Краснопільська, Вільшанська, Бочечківська, Степанівська, Верхньосироватська, Коровинська, Комишанська, Буринська, Дубов'язівська, Чернеччинська, Новослобідська, Тростянецька, Чупахівська, Андріяшівська, у 2018 році - 5 ОТГ: Путивльська, Шосткинська та Білопільська міські, Річківська та Синівська сільські; у 2019 році: Липоводолинська селищна, Сумська та Конотопська міські ОТГ» (Офіційний сайт Сумської обласної ради, 2019).

Побічним ефектом від реформи децентралізації, який певним чином нівелював ії успіхи на Сумщині, став конфлікт між Сумською обласною радою та Сумською міською радою, що розпочався у кінці 2018 р. і набув суттєвого загострення у 2019 р. Конфлікт пов'язаний з перереєстрацією підприємств обласної комунальної власності поза територією обласного центру.

Ще наприкінці 2018 р. ряд підприємств обласної комунальної власності, які розташовані на території обласного центру міста Суми, змінили «прописку», зареєструвавшись у різних населених пунктах Сумської області. Ініціатором такої перереєстрації, на думку мерії Сум, стала обласна рада. У мерії зазначали, що через це бюджет міста втратить 74 млн. грн. податків, які тепер будуть сплачуватись у місцеві бюджети населених пунктів області. У кінці 2018 року з цього приводу міський голова Сум Олександр Лисенко скликав позачергову сесію для звернення до президента, Кабінету Міністрів та інших центральних органів центральної влади.

У березні 2019 р. конфлікт знову загострився, коли у міській раді дізналися, що пенітенціарні установи міста Суми (Сумський слідчий ізолятор та виправна колонія № 116) сплачують податок на доходи фізичних осіб (ПДФО) до бюджету села Косівщина, тоді як їхні юридична адреса та 
місцезнаходження - в Сумах (Інформаційний портал Сумської міської ради, 2019a).

У протистоянні між Сумською обласною радою та Сумською міською радою спостерігалося використання арсеналу «брудних» політичних технологій. Наприклад, в електротранспорті міста Суми розвішувалися листівки, спрямовані на клеймування облради з боку міськради. Також у міськраді лунали погрози розвісити бігборди 3 портретами обласних чиновників, які, на їхню думку, обкрадають міський бюджет. Натомість, 3 боку працівників облради було зафіксовано спробу відключити від Інтернету мерію Сум (Sumy.Today, 2019b).

У травні (13.05.2019 р.) Сумський міський голова Олександр Лисенко повідомив на апаратній нараді, що до перереєстрації з міста Суми у район готується Сумський державний університет. Через такі дії О. Лисенко вирішив звернутися до СБУ та поліції. Також міський голова пообіцяв відключити воду i каналізацію університетам, які перереєструються у райони. Міський голова Сум Олександр Лисенко заявив, що буде закликати людей на майдан Незалежності аби протестувати проти дій обласної влади, через яку сумчани позбавлені 80 млн грн. бюджетних надходжень у зв’язку 3 перереєстрацію своїх підприємств до районів області (Ваш шанс, 2019а).

3 боку Сумської обласної державної адміністрації (ОДА) 13.05.2019 р. Вадим Акперов (тимчасово виконуючий обов’язки Сумської ОДА) заявив, що претензії Сумської міської влади щодо тиску на підприємців 3 питань перереєстрації бізнесу в інших населених пунктах $\epsilon$ необгрунтованими, оскільки не було наведено ніяких аргументів та ніяких фактів. Він висловив припущення, що підприємці перестали довіряти власні податки цій владі через корупційні скандали, які останнім часом виникають навколо міської влади.

У роботі системи голосування «Рада» під час сесійного засідання Сумської міської ради 15.05.2019 р. стався збій, через що у Сумську міську раду викликали СБУ. За словами голови міста Олександра Лисенка, ситуація 
стосовно перешкоджання діяльності депутатського корпусу почала носити системний характер: раніше у приміщенні вимикали освітлення, згодом була порушена робота Інтернет-мережі, наразі - збій у системі «Рада». «Ця система належить обласній раді, їхній адмін повинен слідкувати за нею, у нас немає доступу до серверу» (Інформаційний портал Сумської міської ради, 2019b).

Депутати Сумської міської ради 15.05 .2019 р. звернулися до керівництва країни, правоохоронних органів та області 3 проханням втрутитись у ситуацію щодо перереєстрації обласних підприємств. У тексті звернення зазначалося, що у грудні 2018 року керівництвом Сумської обласної ради здійснювалися заходи, спрямовані на примушування керівників підприємств обласного підпорядкування, які розташовані у Сумах i засновником яких є Сумська обласна рада, вносити зміни до Єдиного державного реєстру стосовно місцезнаходження, не змінюючи при цьому фактичного місцезнаходження. Врешті, на травень 2019 року було змінено місцезнаходження 43 (iз 70-ти) підприємств та установ (закладів) комунальної форми власності, засновниками яких є Сумська обласна рада (Sumy.Today, 2019a).

Заручником конфлікту (битви за податки) між Сумською міською радою та Сумською обласною радою став Сумський обласний наркодиспансер. Обласний наркодиспансер звернувся до депутатів Сумської міської ради з проханням передати їм приміщення на пр. Курському, 111, яке багато років займав на правах безкоштовного користування комунальний заклад «Сумський обласний центр профілактики і боротьби зі СНІДом». Це звернення розглядалося на засіданні депутатської комісії міськради з питань комунального майна i законності 14.05.2019 p. Юрисконсульт наркодиспансеру Оксана Гольченко розповіла членам комісії, що в минулому році Сумський обласний центр профілактики і боротьби зі СНІДом був реорганізований шляхом приєднання до обласного наркодиспансеру, i на сьогодні СНІД-центр як самостійну юридичну особу вже ліквідовано. У 
зв’язку з цим колишній центр зараз переоформляє всі свої документи і договори, в тому числі з постачальниками комунальних послуг (світло, вода та ін.) і 3 іншими організаціями. I всі ці організації просять офіційний документ, що підтверджує право користування приміщенням.

Тобто, по суті, питання було, здавалося б, чисто формальним. Але на ділі все виявилося не так просто. Першим же питанням, яке поставили члени комісії представнику наркодиспансеру, було наступне: де зареєстрований наркодиспансер як юридична особа? Виявилося, що в Краснопіллі. У відповідь пролунало, щоб із зверненнями у Краснопілля і зверталися, i там просили, оскільки податки наркодиспансер платить там, тобто, піднімає Краснопільську громаду. У результаті при голосуванні всі члени комісії утрималися, і рішення про передачу приміщень обласному наркодиспансеру не було підтримане. Таким чином, через конфлікт між Сумською обласною радою та Сумською міською радою, пов’язаний 3 перереєстрацією підприємств обласної комунальної власності поза територією обласного центру, у обласного наркодиспансеру виникли проблеми з переоформленням договорів щодо постачання комунальних послуг (Ваш шанс, 2019b).

Протистояння між Сумською обласною радою та Сумською міською радою частково спричинило ситуацію щодо недостатньої забезпеченості хворих препаратами інсуліну у місті Суми. Оскільки задля забезпечення препаратами інсуліну хворих цукровим і нецукровим діабетом у місті Суми не вистачало коштів, з Міністерства охорони здоров'я надійшла стандартна відповідь щодо необхідності знайти відсутне фінансування в рамках місцевого бюджету. Відсутність фінансування з боку місцевих владних органів призвело до протестних акцій. У квітні 2019 р. батьки дітей, які хворіли на діабет, пікетували у Сумах міську раду, обласну раду i облдержадміністрацію, вимагаючи вирішити проблему з недофінансуванням закупівель інсуліну. Питання було винесене на сесію Сумської міської ради і навіть частково проблема вирішилася. Втім, ця проблема знову актуалізувалася влітку 2019 р. (Сумські дебати, 2019а). 
Сумський міськвиконком у серпні 2019 р. заслухав звіт за пів року щодо виконання міського бюджету. Результати виявилися невтішні. Через перереєстрацію обласних комунальних підприємств, на думку представників мерії міста Суми, бюджет Сум втратив майже 5\% доходів (Сумські дебати, 2019c).

У серпні 2019 р. загострилася ситуація, що склалася навколо підприємств Сумської обласної ради, які розташовані на території міста Суми, але перереєстровані у Сумському, Краснопільському та Білопільському районах області.

Оскільки, з точки зору представників Сумської міської ради, міський бюджет недоотримує податки від підприємств, які юридично переведені 3 міста в райони області, міська рада судиться із Сумською обласною радою. Як зазначив міський голова міста Суми Олександр Лисенко, нестача коштів у міському бюджеті на 27.08.2019 р. становить вже 55,8 млн. грн. (Сумські дебати, 2019b).

Висновки і перспективи подальших досліджень. Побічним ефектом від реформи децентралізації, який певним чином нівелював іiі успіхи на Сумщині, став конфлікт між Сумською обласною радою та Сумською міською радою, що розпочався у кінці 2018 р. і набув суттєвого загострення у 2019 р. Конфлікт пов'язаний 3 перереєстрацією підприємств обласної комунальної власності поза територією обласного центру.

Разом $з$ тим, слід розуміти, що місце реєстрації підприємства - це виключне право засновників та керівників підприємств будь-якої форми власності. Тому для активізації надходжень до місцевого бюджету необхідно налагоджувати співпрацю 3 підприємцями, створювати додаткові умови для розвитку бізнесу саме на цій території, залучати найбільших платників податків до громадських консультацій щодо планування бюджетів. Також необхідно більш активно залучати мешканців до розподілу бюджетів та планування надходжень.

У цілому, Сумській міській раді бажано було б сфокусувати увагу на 
впровадженні програм, спрямованих на відкритість бюджетів, залученні представників бізнесу до створення соціальних проектів та програм. Слід було розібратися з ситуаціями конфліктів міської ради та підприємців задля прогнозного збільшення довіри до Сумської місцевої влади.

Власне кажучи, така ситуація не сприяє суспільно-політичній стабільності в регіоні, оскільки існує ризик збурення громадськості, обумовлений суспільними розколами, які здійснюються владними органами: жителі великого міста (обласного центру) протиставляються жителям сіл і містечок області. Боротьба за бюджетні кошти між владними інституціями може спровокувати глибокі суспільні розколи між мешканцями сіл та міст області. Оскільки гібридна війна Росії проти України базується на створенні та поглибленні суспільних розколів, ця ситуація потенційно може бути використаною Росією в інформаційних деструктивних технологіях проти Сумської області, з якою вона межує.

Крім того, через протистояння двох владних легітимних структур регіонального рівня існує ризик катастрофічного зниження рівня довіри населення до владних інститутів взагалі. Це потенційно формуватиме в очах населення образ держави як слабкої та нездатної у кризові моменти захистити своїх громадян.

Через зменшення рівня надходжень податків до бюджету Сум можлива ситуація, коли будуть недофінансуванні або взагалі зупинені соціальні програми та виплати мешканцям Сум, що значно підірве авторитет центральної влади. Ця може спричинити відкриті маніпуляції громадською думкою та політичними вподобаннями виборців напередодні місцевих виборів 2020 року. Найгіршим є те, що означені ситуації протистоянь нівелюють успіхи реформи децентралізації.

Владні структури здатні формувати комфортне середовище життя громади лише за умови активної співпраці між владою та громадою. Це передбачає необхідність посилення взаємодії на рівні «влада-громада» задля ефективності процесу децентралізації в Україні. В означеному контексті 
завданням кожного громадянина України сьогодні $\epsilon$ зміна власного ставлення, власної свідомості у напрямку створення комфортного середовища життя в своєму селі, селищі, місті. Важливо сформувати у людей бажання брати активну участь у громадському житті, співпрацювати 3 органами місцевого самоврядування для реалізації їх прав на комфортний рівень життя, отримання освітніх, медичних, культурних, соціальних, житлово-комунальних та адміністративних послуг.

Статус територій комфортного середовища життя громади, де сформовані довірливі зв'язки між владою та громадянами, здатні набути додаткової привабливості в плані залучення інвестицій, розвитку різноманітних бізнес-проектів, формування туристичної інфраструктури. Забезпечення високих стандартів якості життя сприяє зниженню конфліктного потенціалу місцевих жителів, відсуває на задній план різноманітні протиріччя, пов'язані з співіснуванням різних соціальних груп в межах одного регіону. Комфортне середовище життя призводить до підвищення самооцінки населення, що обумовлюватиме самоорганізацію індивідів на місцевому рівні, сприяючи появі різноманітних самоврядних ініціатив.

\section{ЛІТЕРАТУРА}

1. Безрук, О. О., 2017. Політична участь як чинник політичної мобілізації: теоретичний аспект. Сучасне суспільство: політичні науки, соціологічні науки, культурологічні науки, 1 (13), с. 16-24.

2. Ваш шанс, 2019а. В Сумах назревает второй майдан? [online] (Останнє оновлення 19 Травень 2019) Доступно: http://www.shans.com.ua/?m=inews\&nid=36527 [Дата звернення 8 Листопад 2019].

3. Ваш шанс, 2019b. Депутаты Сумского горсовета «зажали» помещение для областного наркодиспансера. [online] (Последнее обновление 22 Май 2019) Доступно: http://www.shans.com.ua/?m=inews\&nid=36579 [Дата обращения 10 Ноябрь 2019].

4. Гібернау М., 2012. Ідентичність нащзій. Переклад з англійського П. Таращука. Київ : Темпора.

5. Денисенко, І. Д., 2015. Теорія соціального простору: евристичний потенціал щодо соціально-політичних досліджень. Сучасне суспільство : політичні науки, соціологічні науки, культурологічні науки, 2 (10), Ч. 2, с. 27-37. 
6. Інформаційний портал Сумської міської ради, 2019а. Володимир Войтенко: Податки установ пенітенціарних служб, розташованих у Сумах, мають бути повернені до міського бюджету. [online] (Останнє оновлення 12 Березень 2019) Доступно: https://smr.gov.ua/uk/novini/pro-golovne/13494-volodimir-vojtenko-podatkiustanov-penitentsiarnikh-sluzhb-roztashovanikh-u-sumakh-mayut-buti-poverneni-domiskogo-byudzhetu.html [Дата звернення 8 Листопад 2019].

7. Інформаційний портал Сумської міської ради, 2019b. Олександр Лисенко: Наполягатиму на розслідуванні причин збою в роботі системи голосування «Рада». [online] (Останнє оновлення 15 Травень 2019) Доступно: https://smr.gov.ua/uk/novini/podiji/14249-oleksandr-lisenko-napolyagatimu-narozsliduvanni-prichin-zboyu-v-roboti-sistemi-golosuvannya-rada.html [Дата звернення 20 Листопад 2019].

8. Куц Г. М., 2007. Проблематика ідентичності в ліберальному контексті. Вісник Харківського національного університету імені В.Н.ККаразіна. «Питання політології», 785 (10), с. 79-85.

9. Куц, Ю. О. ред., 2011. Територіальна громада: знаннєвість, дієвість: монографія. Харків : ХарРІ НАДУ : Апостроф.

10. Куц, Ю. О. ред., 2013. Територіальна громада : управління розвитком: монографія. Харків : Константа.

11. Міністерство регіонального розвитку, будівництва та житлово-комунального господарства України, 2019. Моніторинг процесу децентралізації влади та реформування місиевого самоврядування станом на 10 вересня 2019 року. [online] Доступно: http:/www.minregion.gov.ua/wp-content/uploads/2018/12/10.09.2019.pdf [Дата звернення 20 Листопад 2019].

12. Офіційний сайт Сумської обласної ради, 2019. Довідка про виконання в Сумській області вимог Закону України «Про добровільне об'єднання територіальних громад». Децентралізація-2019. [online] (Останнє оновлення 19 Червень 2019). Доступно: https://sorada.gov.ua/actual/40-misc-actual/20400 [Дата звернення 10 Листопад 2019].

13. Патнам Р. Д., Леонарді, Р. та Нанетті Р. Й., 2001. Творення демократії. Традииії громадської активності в сучасній Італії. Переклад 3 англійської. Київ: Видавництво Соломії Павличко «Основи».

14. Сумські дебати, 2019а. Гроші на інсуліни в Сумах знову закінчилися. [online] (Останне 21 оновлення Червень 2019) Доступно: http://debaty.sumy.ua/news/medicine/groshi-na-insulini-v-sumah-znovu-zakinchilisya [Дата звернення 10 Листопад 2019].

15. Сумські дебати, 2019b. Мерія Сум судиться з облрадою за мільйони. [online] (Последнее обновление 27 Август 2019). Доступно: http://debaty.sumy.ua/news/politics/meriya-sum-suditsya-z-oblradoyu-za-miljoni [Дата обращения 10 Ноябрь 2019]

16. Сумські дебати, 2019c. Через перереєстрацію обласних КП бюджет Сум втратив майже 5\% доходів. [online] (Останнє оновлення 20 Серпень 2019) Доступно: http://debaty.sumy.ua/news/economics/cherez-perereyestratsiyu-oblasnih-kp-byudzhetsum-vtrativ-majzhe-5-dohodiv [Дата звернення 20 Листопад 2019]. 
17. Sumy.Today, 2019a. Міські депутати звернулися до керівництва країни, правоохоронних органів та області втрутитись у ситуаџію з перереєстрацією обласних підприємств. [online] (Останнє оновлення 15 Травень 2019) Доступно: http://sumy.today/miski-deputaty-prosyat-kerivnyctvo-krayiny-pravoohoronnyh-organivta-oblasti-vtrutytys-u-sytuaciyu-z [Дата звернення 8 Листопад 2019].

18. Sumy.Today, 2019b. У Сумах працівники обласної ради перекусили кабелі міській. [online] (Останнє оновлення 13 Березень 2019) Доступно: http://sumy.today/u-sumahpracivnyky-oblasnoyi-rady-perekusyly-kabeli-miskiy [Дата звернення 20 Листопад 2019].

\section{Інформація про авторів}

Куц Галина Михайлівна - доктор політичних наук, професор, професор кафедри політології, соціології і культурології Харківського національного педагогічного університету імені Г.С. Сковороди; е-mail: galyna.kuts@i.ua; ORCID: https://orcid.org/00000002-7263-1958;

Нестеренко Віктор Вікторович - головний консультант відділу досліджень Східного регіону в місті Харкові Національного інституту стратегічних досліджень; e-mail: agropua@ukr.net; ORCID: https://orcid.org/0000-0002-3150-803X.

Стаття надійшла до редакції: 02.12.2019 р. $\quad$ Прийнята до друку: 17.12.2019 p. 